\title{
Knowledge of human papillomavirus and Pap test among Brazilian university students
}

\author{
(D) Aimée Denzeler Baptista ${ }^{1}$ \\ (iD) Carolina Xavier Simão' \\ Vitoria Carvalho Guimarães dos Santos ${ }^{1}$ \\ (iD) Juliana Gil Melgaço ${ }^{2}$ \\ DSilvia Maria Baeta Cavalcanti ${ }^{3}$ \\ (iD) Sandra Costa Fonseca ${ }^{4}$ \\ (iD) Claudia Lamarca Vitral ${ }^{3}$
}

\begin{abstract}
1. Medical Student, Faculty of Medicine, Fluminense Federal University, Niterói, RJ, Brasil 2. Posdoctoral Student, Laboratory of Technological development on Virology, Oswaldo Cruz Institute, Fiocruz, Rio de Janeiro, RJ, Brasil 3. Full Professor, Department of Microbiology and Parasitology, Fluminense Federal University, Niterói, RJ, Brasil 4. Associate Professor, Department of Epidemiology and Biostatistics, Fluminense Federal University, Niterói, RJ, Brasil Study conducted at the Biomedical Institute, Department of Microbiology and Parasitology, Fluminense Federal University, Niterói, RJ, Brasil, and Centre for Remote Education of the State of Rio de Janeiro, São Gonçalo Unit, São Gonçalo, RJ, Brasil
\end{abstract}

http://dx.doi.org/10.1590/1806-9282.65.5.625

\section{SUMMARY}

OBJECTIVE: Human papillomavirus (HPV) is the most prevalent sexually transmitted virus in the world and is associated with an increased risk of cervical cancer. The most effective approach to cervical cancer control continues to be screening through the preventive Papanicolaou test (Pap test). This study analyzes the knowledge of university students of health science programs as well as undergraduate courses in other areas of knowledge on important questions regarding HPV.

METHOD: Four hundred and seventy-three university students completed a questionnaire assessing their overall knowledge regarding HPV infection, cervical cancer, and the Pap test. A descriptive analysis is presented, and multivariate analysis using logistic regression identified factors associated with HPV/cervical cancer information.

RESULTS: Knowledge was higher for simple HPV-related and Pap test questions but was lower for HPV interrelations with genital warts and cervical cancer. Being from the health science fields and having high income were factors associated with greater knowledge. Only the minority of the participants recognized all the situations that increased the risk of virus infection presented in the questionnaire.

CONCLUSIONS: These findings highlight the need for educational campaigns regarding HPV infection, its potential as a cervical cancer agent and the forms of prevention available.

KEYWORDS: Papillomaviridae. Uterine cervical neoplasms. Papanicolaou test. Students. Knowledge.

\section{INTRODUCTION}

Human papillomavirus (HPV) is the most prevalent sexually transmitted virus worldwide. According to two recent meta-analyses, prevalence rates of 11 and $12 \%$ are observed in the general population ${ }^{1,2}$. Although an initial peak of the disease is observed in women younger than 25 years, there is an increase in the prevalence of HPV in women of 45 years of age or older in the Americas and Africa ${ }^{1,2}$. The most common types of HPV worldwide in women with regular cytology are $16,18,58,52$, and 31 , in this order. In Brazil, the prevalence of cervical infection by HPV ranges from $13.7 \%$ to $54 \%^{3}$, while in wom-

DATE OF SUBMISSION: 14-Oct-2018

DATE OF ACCEPTANCE: 24-Nov-2018

CORRESPONDING AUTHOR: Claudia Vitral

Departamento de Microbiologia e Parasitologia, Instituto Biomédico, Universidade Federal Fluminense.

Rua Prof. Hernani Melo 101, Niterói, RJ - 24210-130, Brasil

E-mail: clvitral@id.uff.br 
en presenting regular cytology it ranges from 10.4\% to $24.5 \%$, according to studies carried out between 1989 and $2008^{4}$.

HPV cervical infections are mostly self-limited, regressing spontaneously between 12 and 30 months, even when caused by high-risk genotypes, such as HPV16 and HPV18 ${ }^{5}$. Women with persistent HPV infection may progress to cervical intraepithelial neoplasia (CIN) in a rate of $8-28 \%$.

In Brazil, cervical cancer is the third most prevalent type of cancer in women, excluding non-melanoma skin. By 2017-2018, the incidence rate of $15.4 / 100,000$ women $(16,370$ new cases/per year) and mortality rate of 5 out of 100,000 women $(5,400$ deaths) were estimated ${ }^{7}$.

The most effective approach to cervical cancer control is still screening through the Papanicolaou test (Pap test) ${ }^{8}$. Following the introduction of HPV vaccines, studies showed different levels of effectiveness in both strategies, either alone or combined ${ }^{9-13}$. The Pap test is quick, relatively inexpensive, and effective for the early detection of cervical cancer since it identifies cellular morphological changes resulting from HPV infection. However, awareness of the importance of HPV, the Pap test and the need for periodic screening are by no means widespread among sexually active women ${ }^{8,14-16}$. Factors that could explain the lack of knowledge concerning HPV infection and its relation to cervical cancer, as well as the lack of knowledge about the Pap smear test, include a low level of formal education, low income, and difficulty of access to the public health system ${ }^{8,14-16}$. Dissemination of information to women on this subject is of great relevance for disease prevention.

Several studies carried out in Brazil investigated the knowledge of the subject among university students ${ }^{17-24}$. All of them were descriptive studies using convenience samples, varying from 58 and 447 subjects interviewed, and none analyzed factors associated with awareness of HPV and its prevention ${ }^{17-24}$. It was expected that university students would know the subject in more depth since they have access to higher education. However, results showed varying levels of information. So far, only one study compared university students from different fields, and health science students performed better than those from non-health sciences ${ }^{21}$.

Our hypothesis was that the awareness about HPV, the Pap smear test and its relation to cervical cancer is still low even among educated women, de- pending on factors such as age and income. The aim of this study is to verify this hypothesis, analyzing knowledge of the subject by university students from two public institutions of the southeast of Brazil.

\section{METHODS}

This was a cross-sectional study conducted with students from the Fluminense Federal University (UFF) and the Centre for Remote Education of the State of Rio de Janeiro (CEDERJ) between January and December 2015. Students attended health science undergraduate courses (medicine, nursing, veterinary medicine, pharmacy, dentistry, biomedicine, and biology) as well as undergraduate courses of other areas of knowledge (Chemistry, Administration, Accounting Sciences, Computer Sciences, and Mathematics). Participants were recruited during class breaks as well as in the classrooms on scheduled exams. Participation was voluntary, and inclusion occurred by spontaneous demand. Inclusion criteria were: females, and age equal to or greater than 18 years old.

Sample size calculations were based on a $90 \%$ estimated HPV knowledge prevalence for students from health sciences undergraduate courses (group 1) and $60 \%$ for students from other fields of study (group 2), with a $5 \%$ precision rate and a $95 \%$ confidence level, according to previous studies ${ }^{17-24}$. The formula for sample size determination (OpenEpi Epidemiologic Calculator 2006) indicated a total of 101 and 208 participants from groups 1 and 2, respectively. To compensate for possible losses, the number of participants was increased by $50 \%$ in both groups.

Students completed a questionnaire with questions about age (10-year intervals), family income (number of minimum wages per month, classified as high, > 7; medium, 3 to 7; and low, < 3), field of study (health sciences/other) and multiple choice questions on knowledge of the Pap test (frequency, interpretation of the result, and if the participant returns to receive the results), and HPV (main outcomes related to infection: genital warts and cervical cancer, and risk factors for virus infection: two related to sexual partnership, one on the use of condoms, and the other on first sexual intercourse). At the end of the interview, each participant received a folder with main issues asked on the questionnaire.

The study was approved by the Faculty of Medicine Ethics Committee from UFF (CAAE 
14660613.2.0000.5243). All respondents were explained the goals of the study, and written consent was obtained. Confidentiality of data was kept throughout the study.

Data were entered and analyzed using IBM SPSS Statistics version 23. Descriptive analysis used means for continuous variables and proportions for categorical ones, testing differences on knowledge, according to the undergraduate field of study, by t-tests and chi-square, respectively. Multivariate analysis was performed by logistic regression to estimate OR and its $95 \%$ confidence interval for variables such as income, age, and undergraduate field of study.

In multivariate analysis, variables were dichotomized as follows: high income (greater than or equal to seven minimum wages) compared to low income (less than seven minimum wages); health sciences compared to other fields of study. For age, the cut-off point of 25 years of age was used, considering the age limit proposed by the Brazilian Ministry of Health to initiate the investigation of cervical cancer.

\section{RESULTS}

Four hundred and seventy-three university students were interviewed, 154 from health sciences and 319 from other fields of study. The mean age of participants was of 29.8 years old. Significant statistical difference between fields of study, with younger women composing the health sciences field (Table 1) was observed. As for family income, there was also a difference between fields of study, with a higher con- centration of high income in the health sciences field (Table 1).

Results related to participants' knowledge on HPV and the Pap smear test are presented in Table 2. Most participants were aware of what the test is, as well as the periodicity in which it should be carried out. However, $30.4 \%$ were unaware of the meaning of an altered outcome, and 30\% stated that they did not return to the doctor's office to receive the results. Regarding HPV, although most participants had already heard of the virus, $52.4 \%$ of the students did not associate the virus with genital warts, and $47.8 \%$ did not associate it with cervical cancer either. Knowledge related to HPV and the Pap smear test was significantly higher among students from the health science field compared to students from other areas, except for the interpretation of an abnormal result in the Pap test. Only $10.6 \%$ of participants recognized the four situations that increased the risk of virus infection presented in the questionnaire. Considering dichotomously (up to 2 risk factors/3 or more), $60 \%$ of the students from the health sciences recognized 3 or 4 factors while only $23 \%$ of those from other fields achieved this level of recognition.

A multivariate analysis of factors associated with knowledge on Pap smear test and HPV is shown in Table 3. Knowledge on the Pap smear test $(\mathrm{OR}=4.32$, 95\% CI: 1.75-10.64), as well as its periodicity ( $\mathrm{OR}=$ 2.53, 95\% CI: 1.12-5.71), were higher in individuals with higher family income. Regarding knowledge about HPV, when questioned about the relationship of HPV with genital warts $(\mathrm{OR}=1.70,95 \% \mathrm{CI}$ : 1.15 -

TABLE 1: UNIVERSITY STUDENTS' SOCIODEMOGRAPHIC CHARACTERISTICS, ACCORDING TO THE FIELD OF STUDY

\begin{tabular}{|c|c|c|c|c|c|c|}
\hline & $\begin{array}{l}\text { Total } \\
\mathrm{n}(\%)\end{array}$ & $\begin{array}{l}\text { Health Science } \\
(n=154)\end{array}$ & $\%$ & $\begin{array}{l}\text { Other } \\
(n=319)\end{array}$ & $\%$ & $\mathrm{p}$ \\
\hline \multicolumn{7}{|l|}{ Age } \\
\hline Average (SD) & $29.8(14.1)$ & 24.4 & & 32.5 & & $P^{*}=0.000$ \\
\hline Age group (years) & & & & & & $P^{*}=0.000$ \\
\hline$\leq 19$ & $52(11.0)$ & 23 & 14.9 & 29 & 9.1 & \\
\hline $20-29$ & $248(52.4)$ & 107 & 69.5 & 141 & 44.2 & \\
\hline 30-39 & $101(21.3)$ & 12 & 7.8 & 89 & 28.0 & \\
\hline$\geq 40$ & $61(12.9)$ & 12 & 7.8 & 49 & 5.1 & \\
\hline Not informed & $11(2.4)$ & 0 & 0 & 11 & 3.6 & \\
\hline Family income $e^{\star \star *}$ & & & & & & $P^{* *}=0.000$ \\
\hline High (>7) & $194(41.0)$ & 82 & 53.2 & 112 & 35.1 & \\
\hline Medium (3 to7) & $143(30.2)$ & 30 & 19.5 & 113 & 35.4 & \\
\hline $\operatorname{Low}(<3)$ & $128(27.1)$ & 38 & 24.7 & 90 & 28.2 & \\
\hline Not informed & $8(1.7)$ & 4 & 2.6 & 4 & 1.3 & \\
\hline
\end{tabular}


TABLE 2: UNIVERSITY STUDENTS' KNOWLEDGE ON THE PAPANICOLAOU TEST (PAP TEST) AND HPV ACCORDING TO THE FIELD OF STUDY

\begin{tabular}{|c|c|c|c|c|c|c|}
\hline & $\begin{array}{l}\text { Total }(\mathrm{N}=473) \\
\mathrm{N}(\%)\end{array}$ & $\begin{array}{l}\text { Health Sci- } \\
\text { ence }(N=154)\end{array}$ & $\%$ & $\begin{array}{l}\text { Other } \\
(\mathrm{N}=319)\end{array}$ & $\%$ & $\mathrm{p}$ \\
\hline Have you heard of the Pap test? & & & & & & $p=0.017$ \\
\hline Yes & $430(90.9)$ & 147 & 95.5 & 283 & 88.7 & \\
\hline No & $43(9.1)$ & 7 & 4.5 & 36 & 11.3 & \\
\hline What is the periodicity of the Pap test? & & & & & & $p=0.001$ \\
\hline Right answer & $431(91.1)$ & 150 & 97.4 & 281 & 88.1 & \\
\hline Wrong answer & $42(8.9)$ & 4 & 2.6 & 38 & 1.9 & \\
\hline $\begin{array}{l}\text { What is the meaning of an abnormal result on a } \\
\text { Pap? }\end{array}$ & & & & & & $p=0.688$ \\
\hline Right answer & $329(69.6)$ & 109 & 70.8 & 220 & 69.0 & \\
\hline Wrong answer & $144(30.4)$ & 45 & 29.2 & 99 & 31.0 & \\
\hline $\begin{array}{l}\text { Do you return to the doctor's office to collect the } \\
\text { Pap results? }\end{array}$ & & & & & & $p=0.001$ \\
\hline Yes & $331(70.0)$ & 123 & 80.0 & 208 & 65.2 & \\
\hline No & $142(30.0)$ & 31 & 20.0 & 111 & 34.8 & \\
\hline Have you heard of HPV? & & & & & & $p=0.001$ \\
\hline Yes & $447(94.5)$ & 153 & 99.4 & 294 & 92.2 & \\
\hline No & $26(5.5)$ & 1 & 0.6 & 25 & 7.8 & \\
\hline Do you know that HPV may induce genital warts? & & & & & & $p=0.000$ \\
\hline Yes & $225(47.6)$ & 93 & 60.4 & 132 & 41.4 & \\
\hline No & $248(52.4)$ & 61 & 39.6 & 187 & 58.6 & \\
\hline $\begin{array}{l}\text { Do you know that HPV may induce cervical } \\
\text { cancer? }\end{array}$ & & & & & & $p=0.000$ \\
\hline Yes & $247(52.2)$ & 117 & 76.0 & 130 & 40.8 & \\
\hline No & $226(47.8)$ & 37 & 24.0 & 189 & 59.2 & \\
\hline Do you know the risk factors for HPV infection? & & & & & & $p=0.000$ \\
\hline Yes $^{\star}$ & $50(10.6)$ & 33 & 21.4 & 17 & 5.3 & \\
\hline No & $423(89.4)$ & 121 & 78.6 & 302 & 94.7 & \\
\hline
\end{tabular}

* Participants who recognized the four HPV risk factors presented in the questionnaire were classified as "yes": having multiple sexual partners, having a sexual partner who has had several sexual partners, initiating sexual life before the age of 18 and not using a condom.

TABLE 3: FACTORS ASSOCIATED WITH KNOWLEDGE ON PAP TEST AND HPV (ADJUSTED OR/95\% CONFIDENCE INTERVAL)

\begin{tabular}{|c|c|c|c|c|c|c|c|c|}
\hline & \multicolumn{4}{|l|}{ PAP smear test } & \multicolumn{4}{|l|}{ HPV } \\
\hline & $\begin{array}{l}\text { Knowledge on } \\
\text { Pap test }\end{array}$ & $\begin{array}{l}\text { Knowledge } \\
\text { on Pap test } \\
\text { periodicity }\end{array}$ & $\begin{array}{l}\text { Knowledge on } \\
\text { Pap test re- } \\
\text { sults meaning }\end{array}$ & $\begin{array}{l}\text { Knowledge } \\
\text { on the need } \\
\text { to receive Pap } \\
\text { results }\end{array}$ & $\begin{array}{l}\text { Knowledge on } \\
\text { HPV }\end{array}$ & $\begin{array}{l}\text { Knowledge on } \\
\text { relationship } \\
\text { HPV/ genital } \\
\text { warts }\end{array}$ & $\begin{array}{l}\text { Knowledge on } \\
\text { relationship } \\
\text { HPV/cervical } \\
\text { cancer }\end{array}$ & $\begin{array}{l}\text { Knowledge on } \\
\text { risk factors for } \\
\text { HPV }\end{array}$ \\
\hline \multicolumn{9}{|l|}{ Income } \\
\hline $\mathrm{High}^{*}$ & $\begin{array}{l}4.32(1.75- \\
10.64)\end{array}$ & $2.53(1.12-5.71)$ & $\begin{array}{l}1.26(0.82- \\
1.93)\end{array}$ & $1.14(0.74-1.74)$ & $\begin{array}{l}4.16(1.21- \\
14.28)\end{array}$ & $1.70(1.15-2.52)$ & $\begin{array}{l}1.88(1.25- \\
2.83)\end{array}$ & $\begin{array}{l}1.50(0.78- \\
2.88)\end{array}$ \\
\hline Low $^{\star \star}$ & 1.0 & 1.0 & 1.0 & 1.0 & 1.0 & 1.0 & 1.0 & 1.0 \\
\hline \multicolumn{9}{|l|}{ Age } \\
\hline$\geq 25$ years & $1.40(0.71-2.75)$ & $1.15(0.57-2.30)$ & $\begin{array}{l}1.53(0.98- \\
2.37)\end{array}$ & $1.17(0.76-1.82)$ & $\begin{array}{l}0.43(0.15- \\
1.20)\end{array}$ & $\begin{array}{l}1.50(0.99- \\
2.27)\end{array}$ & $\begin{array}{l}0.83(0.55- \\
1.25)\end{array}$ & $\begin{array}{l}1.01(0.49- \\
2.09)\end{array}$ \\
\hline$<25$ years & 1.0 & 1.0 & 1.0 & 1.0 & 1.0 & 1.0 & 1.0 & 1.0 \\
\hline \multicolumn{9}{|l|}{ Field of study } \\
\hline $\begin{array}{l}\text { Health } \\
\text { Science }\end{array}$ & $\begin{array}{l}2.25(0,94- \\
5.37)\end{array}$ & $\begin{array}{l}4.24(1.44- \\
12.50)\end{array}$ & 1.07 (0.67-1.71) & $\begin{array}{l}2.24(1.35- \\
3.70)\end{array}$ & $\begin{array}{l}8.14(1.07- \\
61.93)\end{array}$ & $2.37(1.53-3.67)$ & $\begin{array}{l}3.66(2.31- \\
5.81)\end{array}$ & $\begin{array}{l}4.58(2.28- \\
9.20)\end{array}$ \\
\hline Other & 1.0 & 1.0 & 1.0 & 1.0 & 1.0 & 1.0 & 1.0 & 1.0 \\
\hline
\end{tabular}

*High income: > 7 Brazilian minimum wages per month; * Low income: $\leq 7$ Brazilian minimum wages per month; Baptista AD et al. 
$2.52)$ and cervical cancer ( $\mathrm{OR}=1.88,95 \% \mathrm{CI}: 1.25$ 2.83) (Table 3), we observed that higher knowledge occurred among students with high family income. Being a student of health sciences was associated with greater knowledge about the Pap smear test and HPV in most of the questions used in the investigation. Students from the health sciences field held more knowledge about how often the Pap smear test should be performed ( $\mathrm{OR}=4.24,95 \% \mathrm{CI}$ : 1.44-12.50), the need to get the results (OR $=2.24,95 \%$ CI: 1.35 $3.70)$, the association of $\mathrm{HPV}$ with genital warts $(\mathrm{OR}=$ 2.37, 95\% CI: 1.53-3.67) and with cervical cancer (OR $=3.66,95 \%$ CI: 2.31-5.81), as well as risk factors for infections (OR $=4.58,95 \% \mathrm{CI}: 2.28-9.20)$.

\section{DISCUSSION}

The study corroborated the greater knowledge (more than 90\%) among university women when considering questions such as: a) do you know what the Pap smear test is? b) how often should it be carried out? and c) have you ever heard of HPV? In fact, studies carried out in Brazi ${ }^{14,25-27}$ and in other coun$\operatorname{tries}^{28,29}$ showed that educational level is strongly associated with knowledge of both themes.

However, as the questions became more complex, the level of knowledge on the subject decreased. Although most students know what a Pap smear test is and how often it needs to be performed, $30.4 \%$ of students are unaware of the meaning of an abnormal result. This is concerning since the Pap smear test screening is an important tool for cervical cancer prevention, allowing reduction up to $80 \%$ in mortality from this type of cancer among populations at-risk ${ }^{30}$. As for HPV, despite high knowledge on the virus by most university students, about half of them did not associate the virus with genital warts. This is a matter of concern since self-examination can be critical to recognize clinical active virus infection. Early detection of active infection is important since late diagnosis is associated with increased rates of complications, cancer among them ${ }^{30}$. The relationship between the virus and cervical cancer development was also unknown by about half of the students, and only a minority knew all the associated risk factors. Again, there is an agreement with Brazilian ${ }^{20-25}$ and international studies ${ }^{28,29}$. Caetano et al. ${ }^{24}$ had already described a poor knowledge concerning HPV transmission and its association with genital warts among undergraduate students in São Paulo, Brazil, which might favor their engagement in high-risk sexual behavior ${ }^{25}$. It is worrying to note that this lack of knowledge about HPV can be maintained even among graduated health professionals ${ }^{31}$.

Starting in 2014, the Brazilian Government implemented the quadrivalent HPV vaccine in the National Immunization Program and made it available for girls aged from 9 to 14 years old. The vaccination process was initially carried out in elementary schools, allowing vaccination and educational programs to be carried out together with students. Currently, vaccination is only offered at primary care units. Thus, the opportunity for actions on health education about HPV and related diseases directed at the target public of the vaccine is often missed. Such modification may have resulted in a low adherence to the Program. Official data from the Information System of the National Immunization Program (SI-PNI) showed that in 2014, vaccination coverage rate was around $65 \%$, considerably lower than the $80 \%$ expected $^{32}$, and less than half of the girls took the second dose of the vaccine.

When analyzed by field of study, we observed a higher knowledge of health science students in relation to students from other fields, with statistical significance in seven of the eight questions related to the Pap smear test and HPV, as expected. Multivariate analysis showed a strong association between the field of study and knowledge of frequency and need for returning to get the Pap test results and knowledge in all aspects of HPV. This association was also observed in a city in the south of Brazil21, and in a city in Greece ${ }^{29}$. Health sciences students are privileged by greater access to specific themes and represent future health professionals playing an important role in health education with the population. However, there is still a shortage of knowledge of more complex relationships between HPV, its forms of infection, and related outcomes among these groups of students, with a standard of knowledge similar to that of students from nonhealth fields students. Only $21 \%$ of health students knew the four risk factors associated with HPV. As for non-health students, they generally do not receive formal education on HPV at an undergraduate level. Although lower than that of female health students, the level of general knowledge about the Pap smear test and HPV was greater than that reported in studies with populations of women of different levels of schooling ${ }^{25-29}$. However, for questions of 
inter-relations concerning HPV, cancer, and warts, these university students have an equivalent level of knowledge. Considering the general population over 18 years, Abreu et $\mathrm{al}^{14}$, reported that less than half of the respondents knew about HPV and its associated risk factors, a rate like those here described for students from non-health fields ${ }^{14}$.

It is noteworthy that although the knowledge concerning the importance of the Pap smear test was high, $30 \%$ of the students do not return to the doctor's office to receive test results, invalidating its protective effect in the prevention of cervical cancer. Studies showed a relationship between greater knowledge, risk behavior, and adherence both to the Pap smear test and HPV vaccination ${ }^{29,33-35}$. Therefore, it seems relevant to extend the knowledge of these topics among women of different socioeconomic levels, in addition to university courses in the health sciences area, considering the relevance of HPV-related morbidity and mortality and cervical cancer.

The analysis of the socioeconomic data among university students evidenced that students from health sciences were younger and of higher income families, corroborating studies conducted by the National Student Performance Exam (ENADE - Exame Nacional de Desempenho de Estudantes) throughout the national territory ${ }^{36}$. On the other hand, age, unlike other studies, showed no association with any of the outcomes. Perhaps the form of analysis, with dichotomous variables and the 25-years-old cut-off point, contributed to this result. The result for the income variable was consistent with literature: higher income was associated with greater knowledge on issues related to the Pap smear test and HPV ${ }^{26-28}$. Higher income translates into greater access to information and quality education at the primary and secondary levels, as well as more significant contact with health services and adequate guidelines ${ }^{26,27}$.
Although freely available in SUS (Sistema Único de Saúde), the vaccination program needs to be complemented with educational programs on HPV; otherwise, its effectiveness can be seriously undermined. It is important to note that even if the vaccination coverage rate reaches desirable values, the vaccine does not protect against all HPV genotypes ${ }^{37,38}$. Vaccinated individuals may have the false impression of being permanently protected from the virus as well as from other sexually transmitted infections (STIs).

Strategies to improve vaccination rates should include educational programs to be implemented in schools for the target population of the HPV vaccine, and other approaches designed for different populations, out of school, mainly in primary care ${ }^{39-41}$. At the time of the campaigns, media advertising should be reinforced ${ }^{41}$.

Finally, it is essential that the Cervical Cancer Control Program receives ongoing investment from the Brazilian Ministry of Health, expanding its access to the screening program through Pap test preventive screening.

\section{Acknowledgements}

We thank Lilha Maria Barbosa dos Santos e a Raquel Alves Pinna for assistance with data from the Centre for remote Education of the State of Rio de Janeiro, São Gonçalo Unit (Cederj).

\section{Conflict of interest}

The authors declare no conflict of interest.

\section{Financial support}

This work was supported by grants from the Cecierj Foundation/Cederj Consortium/Remote Education, Rio de Janeiro. Aimée Denzeler Baptista, and Carolina Xavier Simão were supported by a scholarship from the National Council for Scientific and Technological Development (CNPq), Brazil.

\section{RESUMO}

OBJETIVO: O papilomavírus humano (HPV) é o vírus sexualmente transmissivel mais prevalente no mundo, estando a infecção por este agente associada a um aumento do risco do câncer de colo uterino. A abordagem mais eficaz para o controle desse tipo de câncer continua sendo a triagem por meio do exame preventivo (Papanicolaou). Este estudo analisa o conhecimento de estudantes universitárias de cursos da área da saúde, bem como cursos de graduação de outras áreas do conhecimento com relação a questões importantes sobre o HPV.

MÉTODO: Quatrocentas e setenta e três estudantes universitárias responderam a um questionário que avaliava os conhecimentos sobre a infecção pelo HPV, o câncer de colo do útero e o exame preventivo. Após análise descritiva, foi feita a análise multivariada por regressão logística para identificação dos fatores associados à informação sobre o HPV/câncer de colo do útero.

RESULTADOS: O conhecimento das universitárias foi maior para questões simples relacionadas ao HPV e ao exame preventivo, mas 
foi menor para as correlações do HPV com verrugas genitais e com o câncer de colo do útero. Ser aluna da área da saúde e ter alta renda foram fatores associados ao maior conhecimento. Somente uma minoria das participantes reconheceu todas as situações que aumentavam o risco de infecção pelo HPV apresentadas no questionário.

CONCLUSÃo: Os resultados evidenciam a necessidade de realização de campanhas educativas sobre a infecção pelo HPV, do seu potencial como agente de câncer do colo uterino e as formas de prevenção disponíveis.

PalaVRas-Chave: Papillomaviridae. Neoplasias do colo do útero. Teste de Papanicolaou. Estudantes. Conhecimento.

\section{REFERENCES}

1. Bruni L, Diaz M, Castellsagué X, Ferrer E, Bosch FX, Sanjosé S. Cervical human papillomavirus prevalence in 5 continents: meta-analysis of 1 million women with normal cytological findings. J Infect Dis. 2010;202(12):178999.

2. Sabeena S, Bhat PV, Kamath V, Bhat ShK, Nair S, Chandrabharani K, et al. Community-based prevalence of genital human papilloma virus (HPV) infection: a systematic review and meta-analysis. Asian Pac ( Cancer Prev. 2017;18(1):145-54.

3. Colpani V, Bidinotto A, Falavignia M, Benzaken AS, Pimenta C, Maranhão AGK, et al. Prevalência de papilomavírus humano no Brasil: uma revisão sistemática e metanálise. In: 10 Congresso Brasileiro de Epidemiologia da Abrasco, 2017, Florianópolis. Anais do 10ํㅡㄹ Congresso Brasileiro de Epidemiologia da Abrasco, 2017. p. 77057.

4. Ayres AR, Silva GA. Cervical HPV infection in Brazil: systematic review. Rev Saúde Pública. 2010;44(5):963-74.

5. Stanley M. Immune responses to human papillomavirus. Vaccine. 2006;24(Suppl 1):S16-22.

6. Erickson BK, Alvarez RD, Huh WK. Human papillomavirus: what every provider should know. Am J Obstet Gynecol. 2013;208(3):169-75.

7. INCA. Instituto Nacional de Câncer José Alencar Gomes da Silva. Estimativas 2018 para incidência de câncer no Brasil. [Cited on 2018; April 12]. Available from: http://www.inca.gov.br/estimativa/2018/estimativa-2018. pdf

8. Soneji S, Fukui N. Socioeconomic determinants of cervical cancer screening in Latin America. Rev Panam Salud Publica. 2013;33(3):174-82.

9. Yamamoto N, Mori R, Jacklin P, Osuga Y, Kawana K, Shibuya K, et al. Introducing HPV vaccine and scaling up screening procedures to prevent deaths from cervical cancer in Japan: a cost-effectiveness analysis. BJOG. 2012;119(2):177-86.

10. Franco-Figueira S, Cachoeira CV, Petry Hasegawa AC, Kano BY, Souza FH, Poulios N. Cost-effectiveness analysis for cervical cancer screening using HPV tests in Brazil. Value Health. 2015;18(7):A811.

11. Meggiolaro A, Unim B, Semyonov L, Miccoli S, Maffongelli E, La Torre G. The role of Pap test screening against cervical cancer: a systematic review and meta-analysis. Clin Ter. 2016;167(4):124-39.

12. Mezei AK, Armstrong HL, Pedersen HN, Campos NG, Mitchell SM, Sekikubo $M$, et al. Cost-effectiveness of cervical cancer screening methods in low- and middle-income countries: a systematic review. Int | Cancer. 2017; 141(3):437-46

13. Ekwunife OI, O'Mahony IF, Gerber Grote A, Mosch C, Paeck T, Lhachimi SK. Challenges in cost-effectiveness analysis modelling of HPV vaccines in low- and middle-income countries: a systematic review and practice recommendations. Pharmacoeconomics. 2017;35(1):65-82.

14. Abreu MNS, Soares AD, Ramos DAO, Soares FV, Nunes Filho G, Valadão $A F$, et al. Conhecimento e percepção sobre o HPV na população com mais de 18 anos da cidade de Ipatinga, MG, Brasil. Cien Saude Colet. 2018;23(3):849-60.

15. Donati S, Giambi C, Declich S, Salmaso S, Filia A, Ciofi degli Atti ML; et al; PreGio Working group. Knowledge, attitude and practice in primary and secondary cervical cancer prevention among young adult Italian women. Vaccine. 2012;30(12):2075-82.

16. Yanikkerem E, Goker A, Piro N, Dikayak S, Koyuncu FM. Knowledge about cervical cancer, pap test and barriers towards cervical screening of women in Turkey. I Cancer Educ. 2013;28(2):375-83.

17. Cirilo CA, Barbosa AS, Zambrano E. Level of behavior and knowledge concerning human papillomavirus among university students of a nursing college. Rev Soc Bras Med Trop. 2010;43(4):362-6.

18. Andrade TMF, Martins MC, Gubert FA, Freitas CM. Knowledge of nursing students about human papillomavirus infection and vaccination. DST Bras Doenças Sex Transm. 2013;25(2):77-81.
19. Panobianco MS, Lima ADF, Oliveira ISB, Gozzo TO. O conhecimento sobre o HPV entre adolescentes estudantes de graduação em enfermagem. Texto Contexto Enferm. 2013;22(1):201-7.

20. Luz NNN, Lustosa IR, Machado KC, Pacheco ACL, Marques MMM, Peron AP, et al. Acadêmicos, a percepção sobre o papilomavírus humano e sua relação com o câncer cervical. Semina: Ciênc Biol Saúde. 2014;35(2): 91102.

21. Freitas WR, Fedrizzi EN, Aguiar FG. Knowledge among college students and employees of local health units about human papillomavirus and cervical cancer and its implications for public health strategies and vaccination. DST - J Bras Doenças Sex Transm. 2015;27(1-2):40-7.

22. Prado TC, Borges LL, Saddi VA, Santos SHR, Ribeiro AA. Conhecimento dos acadêmicos de uma universidade de Goiás sobre a infecção pelo papilomavírus humano, câncer do colo do útero e vacina anti-HPV. DST - J Bras Doenças Sex Transm. 2016;28(3):79-85.

23. Burlamaqui JC, Cassanti AC, Borim GB, Damrose E, Villa LL, Silva L. Human papillomavirus and students in Brazil: an assessment of knowledge of a common infection: preliminary report. Braz J Otorhinolaryngol. 2017;83(2):120-5.

24. Caetano ME, Linhares IM, Pinotti JA, Maggio da Fonseca A, Wojitani MD, Giraldo PC. Sexual behavior and knowledge of sexually transmitted infections among university students in Sao Paulo, Brazil. Int | Gynaecol Obstet. 2010;110(1):43-6.

25. Rama CH, Villa LL, Pagliusi S, Andreoli MA, Costa MC, Aoki AL, et al. Awareness and knowledge of HPV, cervical cancer, and vaccines in young women after first delivery in São Paulo, Brazil: a cross-sectional study. BMC Womens Health. 2010;10:35.

26. Albuquerque CL, Costa MP, Nunes FM, Freitas RW, Azevedo PR, Fernandes JV, et al. Knowledge, attitudes and practices regarding the Pap test among women in Northeastern Brazil. Sao Paulo Med I. 2014;132(1):3-9.

27. Lima EG, Lima DB, Miranda CA, Sena Pereira VS, Azevedo JC, Araújo JM, et al. Knowledge about HPV and screening of cervical cancer among women from the metropolitan region of Natal, Brazil. ISRN Obstet Gynecol. 2013;2013:930479.

28. Blake KD, Ottenbacher AJ, Finney Rutten LJ, Grady MA, Kobrin SC, Jacobson RM, et al. Predictors of human papillomavirus awareness and knowledge in 2013: gaps and opportunities for targeted communication strategies. Am | Prev Med. 2015;48(4):402-10.

29. Jelastopulu E, Fafliora E, Plota A, Babalis V, Bartsokas C, Poulas K, et al. Knowledge, behaviours and attitudes regarding HPV infection and its prevention in female students in West Greece. Eur Rev Med Pharmacol Sci. 2016;20(12):2622-9.

30. Lorenzi AT, Syrjänen KJ, Longatto-Filho A. Human papillomavirus (HPV) screening and cervical cancer burden. A Brazilian perspective. Virol ). 2015;12:112.

31. Villar LM, Rabello AD, Paula VS. Evaluating knowledge about human papillomavirus infection among Brazilian health professionals. Asian Pac J Cancer Prev. 2011;12(12):3251-6.

32. Ministério da Saúde. Sistema de Informação do Programa Nacional de Imunização. Coberturas vacinais - HPV Quadrivalente D2 - Sexo feminino de 9 a 14 anos de idade. Total Brasil - 2014. [Cited on 2018, April 27]. Available from: http://pni. datasus.gov.br/consulta_hpv_14_C12.php.

33. Fernández-Feito A, Antón-Fernández R, Paz-Zulueta M. Sexual risk behaviors and PAP testing in university women vaccinated against human papillomavirus. Aten Primaria. 2018:50(5):291-8.

34. Ashtarian H PhD, Mirzabeigi E Bs, Mahmoodi E Bs, Khezeli M PhD. Knowledge about cervical cancer and Pap smear and the factors influencing the Pap test screening among women. Int J Community Based Nurs Midwifery. 2017:5(2):188-95. 
35. Yörük S, Açıkgöz A, Ergör G. Determination of knowledge levels, attitude and behaviors of female university students concerning cervical cancer human papilloma virus and its vaccine. BMC Womens Health. 2016;16:51.

36. Ristoff $D$. Democratização do campus: impacto dos programas de inclusão sobre o perfil da graduação. Cadernos do GEA. 2016;9:5-62.

37. Harper DM, Franco EL, Wheeler CM, Moscicki AB, Romanowski B, Roteli-Martins CM, et al; HPV Vaccine Study group. Sustained efficacy up to 4.5 years of a bivalent L1 virus-like particle vaccine against human papillomavirus types 16 and 18: follow-up from a randomised control trial. Lancet. 2006;367(9518):1247-55.

38. Garland SM, Hernandez-Avila M, Wheeler CM, Perez G, Harper DM, Leodolter S, et al; Females United to Unilaterally Reduce Endo/ectocer- vical disease (FUTURE) I Investigators. Quadrivalent vaccine agains human papillomavirus to prevent anogenital diseases. N Engl | Med. 2007;356(19):1928-43.

39. Paul P, Fabio A. Literature review of HPV vaccine delivery strategies: considerations for school- and non-school based immunization program. Vaccine. 2014;32(3):320-6

40. Bonner K, Banura C, Basta NE. HPV vaccination strategies targeting hard-to-reach populations: out-of-school girls in LMICs. Vaccine. 2018;36(2):191-3.

41. Vorsters A, Arbyn M, Baay M, Bosch X, Sanjosé S, Hanley S, et al. Overcoming barriers in HPV vaccination and screening programs. Papillomavirus Res. 2017:4:45-53. 